\title{
COURAGE, FEAR AND IMMIGRATION: THE SIGNIFICANCE OF WELCOMING NEWCOMERS IN A FREE ECONOMY
}

\author{
KEN SCHOOLLAND*
}

Resumen: A lo largo de la historia los pueblos han escapado de la tiranía y de la privación para mejorar su calidad de vida. El rechazo de los refugiados es un acto de colaboración con la tiranía. Aceptar a los refugiados genera importantes beneficios a éstos y a los países receptores. Sin embargo, hay muchos en las economías receptoras que se sienten amenazados por los recién llegados. Estos temores están motivados por ideas colectivistas que asignan incorrectamente la responsabilidad de los problemas asociados con la migración.

Palabras clave: Inmigración, imán del bienestar, leyes anti-laborales, seguridad nacional, bienestar corporativo, proteccionismo, libre comercio, escasez de recursos, libertad económica del mundo, densidad de población, Julian Simon, Fraser Institute, Thomas Jefferson.

Clasificación JEL: F22

Abstract: Throughout history people have fled from tyranny and deprivation to improve their lives. Rejecting refugees is an act of collaboration with tyranny. Accepting refugees brings great benefits both to refugees and to the receiving country. However, there are many in the receiving land who feel threatened by newcomers. These fears are motivated by collectivist notions that incorrectly attribute responsibility for problems associated with migration.

Key words: Immigration, welfare magnet, anti-labor laws, national security, corporate welfare, protectionism, free trade, resource scarcity, Economic

* Julian Simon Memorial Lecture. Liberty Institute, New Delhi, India (January 10, 2005). Ken Schoolland is an Associate Professor of Economics and Political Science at Hawaii Pacific University, and a member of the Mont Pelerin Society, the Board of Directors for the International Society for Individual Liberty, and the Board of Scholars of the Grassroot Institute of Hawaii. Email: schoollak001@hawaii.rr.com, Web site: http://jonathangullible.com/

Procesos de Mercado: Revista Europea de Economía Política Vol. VII, n. ${ }^{\circ}$ 1, Primavera 2010, pp. 157 a 189 
Freedom of the World, population density, Julian Simon, Fraser Institute, Thomas Jefferson.

JEL Classification: F22.

\begin{abstract}
Immigrants' voyages to this land, following upon preparations that required extraordinary effort and often pain, have been among the most exciting and noble of human endeavors. Women and men and children have been strong and brave. They have undertaken their inevitably-frightening transits to a new place for the best of motives: the desire to improve their own lot and that of their families; the urge to leave countries whose governments they could not abide; and the willingness to help build another country where persons can live in freedom and dignity.

Julian Simon, A Life Against the Grain
\end{abstract}

Here we are, a room full of freedom-loving people, where it is safe to cheer for freedom and to denounce repression. Yet even in such a room of fellow travellers, there is one topic that is sure to stir up anxiety and friction.

And that topic is "immigration", which can divide a room faster than almost any other.

So whenever I get nervous about addressing a group on the topic of immigration, I take courage from immigrants themselves.

I

COURAGE

I think of the amazing courage it takes to flee oppression, to leave behind everything that is familiar, and to chance the hostility of a completely alien culture in order to find freedom, opportunity and a better life. When I think of that courage, I am greatly emboldened. How much easier it is to speak to a friendly audience than it is to risk one's life in a rickety boat facing storms, pirates 
and sharks. Or to risk one's life crawling under fences and trudging for hours or days without water across a desert in temperatures exceeding $120^{\circ}$.

I cannot fault those who try. I admire them. Some of my ancestors probably tried something similar, very long ago, and it has benefited me. I can only hope I would have had the same courage had I been in their shoes.

But if I had been a German or Polish Jew in the 1930s, I'm not sure I would have had the courage to flee an increasingly hostile Nazi regime. Would I have defied the authorities and tried to sneak into Switzerland or the US, even though these nations had declared their quotas for German and Polish Jews were full? ${ }^{1}$ Or would I have watched my family being exterminated?

If I had been a Cuban or North Korean in the 1990s, would I have had the courage to hand over a lifetime's savings to the novice captain of a crowded, leaky boat and chance the dangers of the open sea? Or would I have accepted the tyranny of a communist or military dictator who would enslave and impoverish me and my family for decades?

If I had been a Black slave in the antebellum South in the early 1800s, would I have risked the underground railroad - to run from a slave master? Would I have fled to a Northern state where I was considered illegal runaway property that stole itself, and where most people would have been eager to turn me over to the authorities for a swift return to my owner? Or would I have been content to stay where I was, legal and unfree, and watch my family live under tyranny?

All this reminds me of a cherished American hero, Patrick Henry, whose words appear in every American history schoolbook: «Give me liberty or give me death!»

While these words are cherished, do we really cherish those who act upon them? I hope I never have to face such a dilemma. But there are people who do. For the world is still filled with nation masters, rulers who see people as slaves to their will.

\footnotetext{
1 Horberger (1995), The Economist (2002a).
} 


\section{II}

FEAR

What about those who argue against open immigration? Aren't any of the arguments valid? I say no.

Of course there are problems which arise when people move around the planet. I don't deny that. But I don't blame those problems on liberty. Instead I look to see if it is the repression of liberty itself which is causing those problems. And it usually is.

In order to solve problems I don't ask, "What can the government do?» Instead, I ask, «What has the government done to cause or contribute to these problems in the first place?» Undo that and you have a solution.

Underlying every argument against the movement of people to freedom is fear. Such fears are sometimes openly expressed, but more often they are veiled or disguised. The fear of immigrants denotes the absence of courage.

Courage welcomes competition. Fear shuts it out. Courage embraces the newcomer. Fear expels him or her. Courage champions liberty. Fear denies it.

When I think of this fear, I think of the official term for immigrants: «aliens». The authorities call them «aliens», and give them «alien registration» cards.

I've seen a few movies about aliens. Alien, Aliens, Aliens 3 and Alien Resurrection. The movie books show more that 20 listings about aliens, all from outer space.

Such movies are very popular because they tap primal xenophobic fears. The alien movies are typically about hideous foreign creatures who disguise themselves by invading the bodies of beautiful, loving Hollywood humans and their children. All this is done with the purpose of gaining strength and power from the host. The aliens then suddenly break out, conquering and devouring all life as we know it. This approximates the subconscious fear that people everywhere have of immigrants - throughout history.

What are these fears that immigrants arouse? The basic fears have to do with race, culture, change, livelihood, security and crowds. And the rationalisations for exclusion are disguised in many forms. 
III

\section{SLOTHFUL IMMIGRANTS?}

One of the most frequent arguments used by Americans against opening of borders is that immigrants come for welfare and that innocent US taxpayers are compelled to pay for these slothful immigrants. It is an interesting contrast: people fear immigrants for working too hard and taking away jobs, and for working too little and taking away welfare. So which is it?

I am always asking my students about supposedly «slothful immigrants». I ask them to imagine being an employer who is facing two prospective employees. Little is known about the job applicants except this: one is an American citizen and the other is an immigrant. Now which prospective employee do the students identify as the harder worker of the two: the American citizen or the immigrant? They always, always, always say that the immigrant would be the harder worker.

Those who move from one country to another are often the most energetic, the most courageous and enterprising. They leave behind everything that is familiar in order to go to a place where everything is unfamiliar and where everyone is potentially hostile.

When immigrants start businesses in America, hire Americans and offer to sell products to Americans, it is the right of the consumer to buy from these immigrants if he chooses.

And what of American employers? Do employers have a right to hire immigrants if they choose? Consider the words of Robert W. Tracinski, a senior writer for the Ayn Rand Institute:

The irrational premise behind our nation's immigration laws is that a native-born American has a «right» to a particular job, not because he has earned it, but because he was born here. To this «right», the law sacrifices the employer's right to hire the best employees - and the immigrant's right to take a job that he deserves. To put it succinctly, initiative and productiveness are sacrificed to sloth and inertia.

The «American dream» is essentially the freedom of each individual to rise as far as his abilities take him. The opponents 
of immigration, however, want to repudiate that vision by turning America into a privileged preserve for those who want the law to set aside jobs for them - jobs they cannot freely earn through their own efforts... Any immigrant who wants to come to America in search of a better life should be let in - and any employer who wants to hire him should be free to do so. ${ }^{2}$

\section{IV}

\section{TREASURES OF THE EARTH}

And what of the economic consequences of immigrants coming to work? The practical questions have already been answered by the brilliant work of Julian Simon. ${ }^{3}$ According to Simon, immigrants provide extraordinary benefits to a nation. Most immigrants come when they are in their most productive years.

Overall, new immigrants average only one year less in education than the native population of the US, but their children are highly motivated and excel beyond the level of native Americans in school. Immigrants have a higher proportion of advanced degrees than the native population, especially in high productivity areas of science and engineering. Of immigrants who have a background in science and engineering when they go to the US, more than a third are from India. The Economic Times reported last month that median income of Indian-Americans in the US is $\$ 60,000,50 \%$ greater than the average in America. ${ }^{4}$

Immigrants to the US, even those from poor countries says Simon, are healthier in general than natives of the same age. Family cohesion, with a tradition of hard work, is stronger than among natives. Simon also reports on 14 separate studies concluding that immigrants do not cause native unemployment, even among very sensitive categories of low-paid, minority, lowskilled or even high-skilled groups of natives.

\footnotetext{
2 Tracinski (2002).

3 Simon (1995). Another excellent source is Mitra (2000), Ed.

4 Ferguson (2004). See also The Economic Times (2004), December 30.
} 
Another 12 studies revealed that immigrants do not have a negative effect on wages. There is no fixed number of jobs. Enterprising immigrants come with arms, legs and brains that create employment and wealth wherever they settle. Those who have little education have traditionally had the motivation to take on the four D's, work that is either too difficult, too dangerous, too dirty or too dark for most American workers.

Simon concluded from a review of the research that, when they are not prohibited from working by anti-labour laws, immigrants contribute more in taxes than they draw out from government welfare services. And over the years, immigrant earnings exceed the earnings of comparable native groups. Julian Simon asserted that the continuation of welfare benefits for aging citizens may well depend on the contributions of youthful immigrants. ${ }^{5}$

If this is so, why aren't immigrants treated as treasures of the earth? Why aren't politicians the world-over competing with each other to lure these valuable human resources to their land in the same manner that they compete to lure capital investment, the product of all this human labour? Why aren't immigrants seen as an inspiration - as were the immigrants Mikhail Baryshnikov, Enrico Ferme, Irving Berlin and Albert Einstein?

Except for well-to-do tourist, student and business visitors, those newcomers who wish to settle inspire xenophobic fear. This fear will not stop immigrants from the most natural of human impulses, the striving for freedom and opportunity.

During class debates, my students hear all the arguments about immigration with an impressive array of documentation, both pro and con. As the debate rages, the students find themselves torn by the dilemma between fear and ethics.

For me, the ethics are clear: if I do not have the right to stop a person from peacefully pursuing freedom and opportunity, then I do not have a right to ask a politician to do this for me. The law may declare someone illegal, but if his or her actions are moral, then it is the law that is immoral.

\footnotetext{
5 Simon (1995), op. cit., pp. 3-5.
} 


\section{$\mathrm{V}$ \\ HIGH WELFARE CORRELATES WITH OUT-MIGRATION}

This view of personal ethics satisfies many free-marketers in virtually every aspect of economics except immigration. They may accept immigration theoretically, but only after all forms of welfare have been abolished. Which is to say - «Not in my lifetime!» 6

Is it correct to suppose that in-migration is caused by the existence of welfare? If it is true that immigrants go to America for the welfare, then it would follow that once in the country, immigrants would move to the states with the most welfare. But just the opposite is true.

Both the native-born population and the foreign-born population flee states with the highest welfare and move to those with the lowest welfare.

Take Hawaii, for example. According to Michael Tanner and Stephen Moore of the CATO Institute, ${ }^{7}$ the six basic welfare benefits in Hawaii (six among a possible 77 welfare programs) could have provided a mother and two children with the equivalent of a pre-tax income of $\$ 36,000$ or a wage of $\$ 17.50$ an hour, the highest benefits in the nation. This, however, is not associated with net domestic in-migration to Hawaii. According to recent data from the US Census Bureau for the decade of the 1990s, Hawaii experienced net domestic out-migration to other states of both the native-born and the foreign-born population.

Among the ten states that provided the greatest levels of welfare, there was a net out-migration of 1,500,000 native-born and almost 500,000 foreign-born individuals. ${ }^{8}$ Eight of the ten highest welfare states experienced out-migration of the nativeborn.

${ }^{6}$ An excellent presentation of various arguments can be found in Hoppe (1998), Block (1998). Also excellent Horberger (1995).

7 Moore (1995).

8 US Census Bureau (2003). 
VI

LOW WELFARE CORRELATES WITH IN-MIGRATION

Contrast this with states that grant little welfare. Eight of the ten states offering the lowest levels of welfare experienced net domestic in-migration of the native-born population. And nine of the ten low welfare states experienced net domestic inmigration of the foreign-born population.

\begin{tabular}{|c|c|c|c|}
\hline & $\begin{array}{c}\text { Hourly wage } \\
\text { equivalent } \\
\text { of welfare (1995) }\end{array}$ & $\begin{array}{c}\text { Native net } \\
\text { domestic migration: } \\
\text { Number }\end{array}$ & $\begin{array}{l}\text { Foreign-born } \\
\text { domestic net } \\
\text { migration: } \\
\text { Number }\end{array}$ \\
\hline \multicolumn{4}{|l|}{ TOP 10: } \\
\hline Hawaii & $\$ 17.50$ & $-65,505$ & $-10,628$ \\
\hline Alaska & $\$ 15.48$ & $-31,040$ & +542 \\
\hline Massachusetts & $\$ 14.66$ & $-56,324$ & $+1,616$ \\
\hline Connecticut & $\$ 14.23$ & $-66,950$ & $+2,340$ \\
\hline Wash. D.C. & $\$ 13.99$ & $-35,515$ & $-9,816$ \\
\hline New York & $\$ 13.13$ & $-669,102$ & $-205,146$ \\
\hline New Jersey & $\$ 12.74$ & $-186,933$ & $+4,104$ \\
\hline Rhode Island & $\$ 12.55$ & $+2,320$ & +916 \\
\hline California & $\$ 11.59$ & $-518,187$ & $-237,349$ \\
\hline Virginia & $\$ 11.11$ & $+59,364$ & $+16,366$ \\
\hline Top 10 average & $\$ 13.70$ & - & - \\
\hline Total Pop Chg. & - & - 1,567,872 & - 437,055 \\
\hline \multicolumn{4}{|l|}{ BOTTOM 10: } \\
\hline Mississippi & $\$ 5.53$ & $+25,845$ & $+1,085$ \\
\hline Alabama & $\$ 6.25$ & $+25,158$ & +665 \\
\hline Arkansas & $\$ 6.35$ & $+35,049$ & $+7,067$ \\
\hline Tennessee & $\$ 6.59$ & $+135,615$ & $+10,699$ \\
\hline Arizona & $\$ 6.78$ & $+275,814$ & $+40,334$ \\
\hline Missouri & $\$ 7.16$ & $+42,397$ & $+3,656$ \\
\hline West Virginia & $\$ 7.31$ & $-9,778$ & -976 \\
\hline Texas & $\$ 7.31$ & $+131,538$ & $+16,702$ \\
\hline Nebraska & $\$ 7.64$ & $-20,160$ & $+4,807$ \\
\hline S. Carolina & $\$ 7.79$ & $+124,151$ & $+8,054$ \\
\hline Bottom 10 Ave & $\$ 6.87$ & - & - \\
\hline \multirow[t]{2}{*}{ Total Pop Chg. } & & $+765,629$ & $+92,093$ \\
\hline & CATO & US Census & US Census \\
\hline
\end{tabular}

Source: Stephen, «Why Welfare Pays,» Wall Street Journal, September 28, 1995 «Migration of Natives and the Foreign Born: 1995-2000,» US Census Bureau, August 2003. 
There are some high-profile exceptions, but most migration results from a desire for opportunity, not for welfare. People who are too lazy to work are also too lazy to leave everything that is familiar to them and go to a place that is unfamiliar and potentially hostile. This is even more true of people who move across national borders at great personal risk.

In refuting the "welfare magnet theory», the ethical argument is far more appealing than the practical argument. To say that immigrants are responsible for welfare in the US is a collectivist notion. The ethics of individual liberty oblige US to hold people accountable for their own actions, not for the actions of others. Immigrants are no more responsible for oppressive welfare laws in the US than they are for the oppressive tyranny in the country they are fleeing.

We are fortunate that US politicians are beginning to take hold of the runaway welfare system of recent decades. The share of the US population living below the poverty line has fallen to a 21-year low, the number of people on welfare and the percent of the population on welfare have both been cut in half. ${ }^{9}$

The welfare system is not a given. Welfare need not be an excuse for prohibiting immigration. A system of welfare that was created by politicians can also be changed by politicians.

Some opponents of immigration say that refugees ought to stay in their home country to change the political and economic system rather than to move away. I reply that the best judge of this option is the immigrant himself or herself.

Sometimes refugees - in the tradition of Ludwig von Mises, Friedrich Hayek and Ayn Rand -did more to change their homeland from a distance than they would have had they remained behind - to be killed, to rot in the dreary confines of some dungeon, or to slave away at backbreaking toil for a few pennies a day. The immigrant is the best judge of his or her own options, as is the case of all earlier immigrants to America.

\footnotetext{
${ }^{9}$ Investors Business Daily (2000).
} 


\section{VII \\ TROJAN HORSE?}

Another fear, especially in America these days, is concerned with national security. This has certainly commanded a lot more attention since the 9/11 terrorist attack on the World Trade Center. Some have cried out for an end to immigration as a means of keeping terrorists far away. Every ship, barge and airplane is perceived as a potential Trojan Horse.

To the extent that government has any legitimate function, it is to protect the people from a conquering invasion, and it should be intelligent enough to figure this out. I have no problem with denying visas to an invading army, though I suspect that if the North Korean government gave orders to invade the United States in this manner, virtually every starving soldier would become a defector the instant he crossed the border.

It is understandable that, in the aftermath of such a tragic crisis as $9 / 11$, people will, and must, clamour for protective measures against terrorists. But reason must prevail over collectivist repression in order to gain real protection.

The US government has had no shortage of defence expenditures, «spending more than the rest of the world combined». 10 Nevertheless, the US intelligence and security agencies - despite the abundance of wealth, personnel and technology at their disposal- came up short in a decades-long effort to root out a terrorist network with global tentacles which originated in some of the poorest nations of the world.

The villains of 9/11 had long said they wanted an attack on America. The villains had attempted attacks before, even on some of the same targets. The villains are reported to have been within the US government's grasp on earlier occasions, but were not pursued. ${ }^{11}$

Will such attacks in the future be forestalled by stopping all immigration? I think not. This sentiment was recently echoed by the US Secretary of State, Colin Powell.

10 Investors Business Daily (2002).

11 Ijaz (2001) and The Economist (2002b). 
Some argue that we should raise the drawbridge and not allow in any more foreign visitors. They are wrong. Such a move would hand a victory to the terrorists by having US betray our most cherished principles. For our own well being, and because we have so much to give, we must keep our doors open to the world...

Openness is fundamental to our success as a nation, economically, culturally and politically. Our economy will sputter unless America remains the magnet for entrepreneurs from across the world. Our culture will stagnate unless we continue to add new richness to our mosaic. And our great national mission of spreading freedom will founder if our own society closes its shutters to new people and ideas. Openness also is central to our diplomatic success, for our openness is a pillar of American influence and leadership...12

Secretary Powell recognised the importance of openness to leadership, but his department has been closing the door on this leadership. The number of visas granted to scientists and engineers for work in the US has been cut by two-thirds in the past two years. ${ }^{13}$ The fear of foreigners has also led to a tremendous reduction in the number of student visas issued over the past three years. There was, according to Nature magazine, «a 19 percent decrease in the number of foreign students admitted to graduate programmes in the life sciences and a 17 percent drop in admissions in the physical and earth sciences. Admissions from China, India, and South Korea, which between them provide the lion's share of foreign students in the United States, were all down sharply.» 14

Indicative of the effect of increased visa restrictions, the University of Hawaii announced a decline of international student enrollment by 28 percent for next year. These students, with all of their talent and leadership, will go elsewhere to take their classes.

\footnotetext{
12 Powell (2004).

13 Ferguson (2004), op. cit., p. C3.

14 Brumfiel (2004).
} 
Asking for a sweeping end to all immigration sidesteps responsibility for the need to have good intelligence and effective police work. It scapegoats the very refugees who are also the victims of terror. Far better that individual criminal conspirators be effectively - effectively - tracked and brought to justice.

One way to approach the security issue is to examine the actions of government which may have placed American security at risk. For guidance on this, I think two early American Presidents, George Washington and Thomas Jefferson, had it right two centuries ago when they advised against entangling alliances. Jefferson declared in his 1801 inaugural address, «Peace, commerce, and honest friendship with all nations - entangling alliances with none.»

What entangling alliances might Jefferson have warned US against? He might have warned US government officials against the overthrow of the democratically-elected leader of Iran in 1953, placing a tyrant in power for the next 26 years. ${ }^{15}$ Thomas Jefferson would have warned US government officials against the arming of Saddam Hussein for his eight-year-long invasion of Iran. And he might have been suspicious of US government support of Osama bin Laden in the Afghan war in the 1980s.

Interventionist policy makers in the US government may have thought they knew how to manipulate the affairs of foreign nations. But they were dead wrong. Washington and Jefferson had more foresight and were right to warn against such arrogance.

\section{VIII \\ HUMAN TRAFFIC}

According to the US State Department, there are thousands of slaves in the United States. Unbelievable? The Economist magazine reports, «Every year, on State Department estimates, about 50,000 people, the vast majority women and children, are forcibly trafficked into the United States from all over the world - Eastern

15 Honolulu Advertiser (2000). See also Solberg (1976). 
Europe, Asia, Central America, Africa.... They are forced to work as virtual slaves, for the traffickers' profit, in the sex industry, on farms and in factories.» ${ }^{16}$ Beyond that, there are an estimated four million slaves worldwide. ${ }^{17}$

Why don't these slaves in the US today simply run to the police for protection? That's what the police are for, aren't they? But no. As enforcers for deportation, the police unwittingly collaborate to empower black market slave owners. Black market slaves don't run to the police because the police will only deport them to a nation-state where the official slave masters are perceived to be worse. It isn't an attractive choice.

It is for the same reason that, during the 1850s in the US, runaway plantation slaves would not have gone to the police for protection. The police openly collaborated with slave owners. Running away was illegal, but it was moral. The law was immoral.

Runaway slaves could be abused by employers, denied payment for work, beaten or even raped. The slave didn't dare turn to the police for help because the so-called «help» would be deportation to a «state plantation» master where conditions were perceived to be worse. That wasn't an attractive choice either.

This is why slavery persists around the world today. It continues as Burmese, Sudanese, Cubans and North Koreans are hustled back to slave states. Americans are even fined $\$ 3000$ per head for the «crime» of rescuing refugees at sea and bringing them ashore. ${ }^{18}$ Hard as it is to accept, we have not progressed from the horrible time when runaway slaves were captured and forcibly returned to their plantation masters.

It persists because immigration laws provide collaboration with tyranny. These immigration laws should be condemned just as the Fugitive Slave Law of the 1850s was condemned by abolitionists 150 years ago in America.

It isn't enough that the US Coast Guard captures runaways throughout the Caribbean Sea in order to return them to their state masters. The US Department of Homeland Security now

\footnotetext{
16 The Economist (2002c).

17 Shapiro (2002).

18 See Honolulu Advertiser (1993a) and Honolulu Advertiser (1993b).
} 
seems to consider the whole world an American «homeland», sending the Coast Guard thousands of miles to the shores of Ecuador where it has detained more than 4,000 suspected illegal migrants and sunk a dozen emptied boats by setting them ablaze and firing on them with their .50 -caliber guns. ${ }^{19}$

A former student of mine, a member of the US Coast Guard, said he really felt he was in a dilemma because these intensely crowded boats are not at all seaworthy. "Imagine», said Craig, «just imagine falling off one of these boats and seeing it sail off without you.» Yet this near-certainty of death, of a very ghastly death at sea awaiting them, highlights the desperation of refugees. Every trip echoes Patrick Henry, "Give me liberty or give me death!»

It isn't the turbulent water and the rickety boat that kills. If I want to travel to Haiti or Ecuador, I can fly in safety and comfort for a few hundred dollars. The only reason these refugees spend many thousands of dollars for a dangerous journey on a deathtrap is because of border laws.

IX TYRANT AND CORPORATE WELFARE

Americans should not be worried about welfare for immigrants, but there are other forms of welfare, however, that Americans should be alarmed about. Two kinds of welfare help to drive immigrants from their homes: «tyrant aid» welfare and «corporate protectionist» welfare.

The US taxpayer has been compelled to provide tyrant welfare to an extremely sordid gang of thugs over decades: from Duvalier, Mobutu and Marcos, to Pahlavi, Noriega, Suharto - even a billion dollars for Saddam Hussein.

The Center for Defense Information ${ }^{20}$ states that the US sells weaponry to the political elite in 150 nation-states - four-fifths

19 Finley (2004).

20 Center for Defense Information, America's Defense Monitor, Washington, D.C., www.cdi.org. The data cited in the text of this article was derived from their film, «The Human Cost of America's Arms Sales,» Nov. 8, 1998. 
of these nation-states are undemocratic, and two-thirds are listed by the US State Department as having governments that are abusive of human rights.

Since the end of the Cold War and the beginning of endless drug wars, the American share of worldwide arms transfers climbed spectacularly to 70 percent, ${ }^{21}$ most of which is paid for, directly or indirectly, by US taxpayers. This has surely contributed to the ten-fold increase of refugees in recent decades.

Still another form of welfare directly leads to immigration. This is corporate welfare known as "protectionism». Because of trade barriers, American, Japanese and European consumers are prohibited from buying products that workers and entrepreneurs are willing to produce abroad. This is especially true in agricultural and textile sectors that are particularly well-suited to development in less developed countries.

The OECD says that Europe's agricultural protectionism increases food prices by as much as 20 percent. At the same time, farmers and textile manufacturers in poorer countries are hobbled in their efforts to export, and they find subsidised commodities dumped on their domestic markets. ${ }^{22}$

It is much the same in the US where trade barriers currently quadruple the price of sugar for US citizens, from the world market price of 5 cents per pound to the US domestic price of 20 cents per pound. To accomplish these high prices for US consumers, beet farmers were recently paid to plow under 120,000 acres of growing sugar beets. Immigrant farmers are forbidden from coming to the US. Lower income neighbours abroad are banned from selling to US consumers. And many US food processing companies are driven to move abroad.

This is not wise policy. This is lunacy - for the benefit of powerful special interest groups and politicians who betray the public trust.

"If rich countries were to remove the subsidies [to agriculture]...poor countries would benefit by more than three times the amount of all the overseas development assistance

21 Omicinski (1994).

22 The Economist (2002d). 
they receive each year.» ${ }^{23}$ This has been equally true of textile barriers.

The politics of protectionism contributes mightily to the economic troubles of poorer nations. And since politics and economics are so intertwined, why are immigrants separated into two categories: political immigrants and economic immigrants?

I have no sympathy for this distinction. People have troubles with their economic life not because they speak out against their rulers, but because they often wish to act in the marketplace in defiance of their rulers. One cannot separate politics from the economic consequences of politics.

People have a right to their own reasons for moving from one place to another. They do not have to articulate their protest in political forums to be genuine refugees from political repression. In this sense, voluntary economic behaviour is a political action that risks imprisonment, or worse, if one resists the long arm of authority.

\section{$\mathrm{X}$ \\ RUNAWAY SLAVES}

Slaves who ran away from Southern plantations before America's Civil War, may not have articulated their opposition to the political system, but they were political refugees nonetheless, simply in their pursuit of economic freedom. And they had a right to move from areas of low economic freedom to areas of relatively high economic freedom.

It is no accident that whenever trade barriers are raised against poor nations, there is more poverty, more civil strife, more drug running and more migration. Whenever a US president travels to neighbouring countries asking for help in fighting the drug war or for help in stemming immigration, he is always greeted with the request for the US to simply open its doors to trade, especially in farming and textiles. But these requests have fallen on deaf ears.

Finally this month, after decades of restriction, we will have a reduction in world textile barriers. But agricultural barriers remain.

23 The Economist (2001). 
The wealthy nations of the world have it within their power to massively increase prosperity and investment in poorer countries by simply practising what they preach about free trade, but they don't.

When a tsunami ravaged nations of the Indian Ocean a couple weeks ago, the wealthy nations raised great fanfare and noise about the emergency relief aid they were giving. On the other hand, these same wealthy nations have been stone silent about the decades of trade protectionism against exports from Sri Lanka, Indonesia, India, Bangladesh, Malaysia and Thailand. These exports could have increased earnings, investment and prosperity so much that people of the region could have prepared themselves against such calamity with better roads and bridges, better homes and hospitals, better flood control and civil defence warning systems.

Economic growth makes the world much safer from natural disasters. Reports Carlo Stagnaro, «Thanks to scientific progress and a stronger control over nature, the number of victims due to natural disasters is declining. Death rate has fallen by 98 percent in the last century... In absolute terms, this means that - despite the demographic boom which occurred in the meantime - the numbers killed has fallen from 1.2 million casualties at the beginning of the $\left[20^{\text {th }}\right]$ century to 77,000 at the end of it. This is still too many, but it has significantly improved in the last few decades.» ${ }^{24}$ Of course, this is not possible when economic development is blocked.

This is certainly not to say that wealthy nations are solely responsible for poor growth in much of the world. Corruption, inflation, trade barriers and repression are among the political practices that have been crucial factors in preventing many Latin American nations from achieving the extraordinary growth rates of the Asian Tigers.

While starting from roughly the same base in 1950, the Asian Tigers have grown much more than the nations of Latin America. In 50 years, GDP per capita has multiplied 20 to 40 times in the

\footnotetext{
${ }^{24}$ Stagnaro (2004).
} 
Asian Tiger nations versus two to three times in most Latin American nations. Rigoberto Stewart and José Cordiero demonstrated that freer economic systems can make the difference. ${ }^{25}$ And policies of the wealthy nations can either be a help or a hindrance in doing so.

\section{$\mathrm{XI}$}

\section{RESOURCE SCARCITY?}

In 1783, America's first president, George Washington, proclaimed, «...the bosom of America is open to receive not only the opulent and respectable stranger, but the oppressed and persecuted of all nations and religions, whom we should welcome to a participation of all our rights and privileges.»

My critics say, «Okay, so George Washington would have welcomed immigrants two hundred years ago. But in today's world there's not enough room and not enough resources.»

This is false.

In a free society, human beings produce a growing abundance of everything they need. Again, it was Julian Simon to the rescue. Simon demonstrated over and over that resources are not running out, but are constantly becoming more abundant and cheaper.

Michael Cox wrote in an issue of Reason magazine, «Capitalism creates wealth. During the last two centuries, the United States became the world's richest nation as it embraced an economic system that promotes growth, efficiency and innovation.» Real GDP per capita in the US has now reached $\$ 36,000 .^{26}$

Okay, there's growing wealth, but what about the land? Land is fixed. It doesn't increase. Isn't the US too crowded?

Indeed, when people think of opening the borders north of Mexico, my critics imagine crowds of immigrants pouring in. «Where would they all fit?»

While there are a lot of people trying to get into the United States, it is arrogant to assume that everyone in the world wants

25 Stewart (1998).

26 Cox and Alm (2002). 
to be there. Already there are as many as 10 million US citizens who have chosen to live outside of the United States.

While many Americans live abroad, they have the security of knowing they could return during a time of danger. Many immigrants to the US hope to return to their native country as well, when they have established a greater measure of prosperity and security in their lives. Many from India and China are doing this today.

The Fraser Institute publishes a report on Economic Freedom of the World, which shows a high correlation of economic freedom to economic growth. It is the natural impulse of human beings to move to areas of greater economic freedom, where they have greater opportunity to use their talents. Scientists and engineers from India have established some of the most dynamic computer industries in Silicon Valley, and, as regions of India become more economically free, many of these scientists and engineers are now returning there.

This also explains why native American researchers are currently moving away from the US to places like Singapore, which rank even higher in degrees of economic freedom. Reports Charles Piller of the Los Angeles Times, «Salaries in Singapore are comparable to the United States, but living costs here are lower...Even with full-time domestic help, they save more money than would be possible back home.» ${ }^{27}$

This is precisely what happened in the European Union when Spain was admitted to the EU. Once it became clear that the borders were to open, there was a net homeward migration of those who had previously come illegally. Just last year the EU was enlarged by ten new member nations in Eastern Europe. This didn't lead to a mass migration. If anything, it has led to a massive increase of investment opportunities and prosperity for the whole of the EU - or they wouldn't keep enlarging the EU every few years.

People want the opportunities that freedom brings, and most people would be delighted to have that freedom in the land that is most familiar to them. When it isn't possible, they move.

27 Piller (2004). 
In recent years the economic policies of China and India have been more free and there has been more growth. But the policies are not the same everywhere in China. The Fraser Institute reports that economic freedom in various provinces range from the most free to the least free in the world. It is the most free provinces that have become the engines of growth and attracted the most in-migration.

This change is happening in India as well. Several years ago, Nobel prize winning economist Milton Friedman was quoted in an American news special saying, «Indians can do well everywhere except in India. They do so badly because they are not allowed to use their abilities in India. The government tells them what to do.» («Is America \#1,» ABC News Special, September 19, 1999) But this is changing by region and Indians are moving internally to regional engines of growth.

Part of the concern about immigrants is due to a frightening perception of the population bomb. These fears are unfounded. The United Nations reports that fertility rates in both rich and poor countries have been falling for 30 years and continue to fall. In the rich countries, fertility rates are below the replacement rate, which means that without immigration the overall population would decline. One day this will be the case everywhere.

But what about now? The critics say that no country could accommodate the vast number of refugees in the world today!

The earth is far more accommodating than people realise. There is plenty of room for humanity. For a perspective, let's consider the 30 million refugees in the world today.

This includes 12 million refugees who have fled across international borders as well as 18 million more who are estimated to have been displaced within national borders due to civil strife. ${ }^{28}$ Compare this with Hong Kong and just one tiny US state, Hawaii.

\footnotetext{
28 The Economist (1999).
} 


\section{XII \\ LIBERTY AND DENSITY}

Hong kong is known to be one of the most densely crowded places on the face of the earth with 17,500 people per square mile and a per capita income rivaling that of the United Kingdom. Yet few people are aware that living conditions are only as crowded as they are in Hong Kong because 40 percent of the land area is zoned by the government as country park - where people are not allowed to live.

The same is true of Hawaii. There is no lack of land, but there is lack of politically approved zoning. In all of the Hawaiian Islands, less than five percent of the land area is zoned for all commercial and residential use. There would be plenty of room for newcomers on these tiny islands in the Pacific if only the government stood out of the way.

In fact, if people in Hawaii were willing to accept even a third of the population densities of Hong Kong, then all the refugees of the world could live on the Hawaiian Islands - and still 40 percent of the land area could be zoned as country park. If those people were allowed to farm the agriculturally-zoned sugar plantations that have mostly all gone bankrupt in recent years due to high US labour costs, there is no doubt that diligent Chinese, Vietnamese and Filipino newcomers could turn the land into one of abundance without a penny of government subsidy.

Or just take one portion of federal land in the US that is 65 times as great as the Hawaiian Islands, the lands of the Bureau of Land Management. The BLM leases its 270 million acres of land to a few favored cattle ranchers at one-seventh the market rate. This means that for $\$ 1.43$ per month, the federal government provides them with enough land to sustain a cow and a calf. ${ }^{29}$

Surely there are a lot of people around the world who would be willing to pay more than $\$ 1.43$ per month to live on ten acres (five hectares) in a free country? Aren't human beings worth more consideration than cattle? This is especially true at a time

29 The Economist (2002e). 
when Western governments are paying extraordinary sums to farmers not to use their land.

Surely each generation believes that living space is a problem. In 1800 there were five million people living in the United States, some of them complaining about the crowds of newcomers. How could anyone in 1800 imagine a nation of 281 million people living in the United States today?

The nation isn't poorer for having 56 times as many people as 200 years ago. It is much richer. People accept the changes of the past much more easily than they accept the change that is yet to come. The future will bring US ever greater riches, yet people are still afraid.

Afraid? Why? Because, without confidence in the marvelous potential of a free market, people will always be afraid of the unknown.

Donald Boudreaux argues that, by historical standards, the percentage of immigrant population is relatively small and America is far richer and far more capable of absorbing immigrants than ever before.

Compared to 1920, America now has twice as many physicians per person, three times as many teachers per person, and 50 percent more police officers per person than 80 years ago. There is more food, more health care, more residential living space, and there are more jobs than ever before. Says Boudreaux, «The fact is America today is much wealthier, healthier, [more] spacious, and resource-rich than it was a century ago. And we owe many of these advances to the creativity and effort of immigrants.» ${ }^{30}$

\section{XIII}

\section{BOTH MORE CROWDS AND MORE SPACE}

What is the capacity of the United States in the "worst» case scenario - or «best» - depending on your perspective?

The land area of the United States, 30 percent of which is owned by the federal government, could support ten times the

30 Boudreaux (2002). 
current population and it would still be less densely populated than Japan is today. If only one percent of that number was allowed into the US, the country could accommodate the entire refugee population of the world.

The fact is that, aside from the fraction of federal land that is set aside for national parks, the bulk of federal land is managed for the benefit of a very few, privileged citizens. What was once taken from Indians does not now belong to me or to all US citizens. It effectively «belongs» to whoever has power in the councils of government: foresters, cattlemen, miners and environmentalists.

A study of one national forest found that the government spent $\$ 13$ building logging roads for every $\$ 1$ of revenue earned from the sale of timber. This isn't frugal management, this is plunder of the taxpayer for the benefit of special interest lobbies.

I would much rather see governments give greater respect to the private ownership of justly acquired land, rather than taking lands by force with the condemnation powers of eminent domain. And where the government holds land, it should be open to those with a just claim or to homesteading. If this means a livelihood for millions of people instead of cows and prairie dogs, then so be it.

Do US citizens prefer open space to cities? Do they need rolling hills and great expanses between each other? For some, yes. And there is more and more of both types of living, cities and open space, for all.

Generally speaking, Americans are like people everywhere and they prefer to live and work in cities or suburbs, which account for less than 3 percent of the land area of the contiguous 48 states. ${ }^{31}$ Most people like crowded cities or they wouldn't go there. That's where the action is.

That explains why, in the decade of the 1990s, the population of New York State declined, while the population of Metropolitan New York City increased. Likewise, the population of California State declined, while the population of Metropolitan Los Angeles

\footnotetext{
31 Ibid, p. 54.
} 
City increased. So there is both more open space in the countryside and more action in crowded cities.

As anyone who has flown across the United States can affirm, the population is highly concentrated in certain regions. One can fly for hours across vast expanses of land which are virtually uninhabited. Even the most desolate of land becomes inviting when the law permits freedom.

The number one travel destination for residents of Hawaii is to the deserts of Nevada, not for the open spaces, but for the crowded casinos of Las Vegas where gambling is allowed. Legalising games of chance has made Las Vegas one of the fastest growing regions of the country.

When these cities have troubles, it isn't because of the number of people, it is because of the failure of governments to provide the primary protection services that politicians so often promise. Washington DC, the crime capital of the US, is a prime example.

We shouldn't use poor government performance as an excuse for excluding newcomers. Instead, we should seek to improve performance with market alternatives wherever possible.

\section{XIV \\ THE ETHICS OF LIBERTY}

Every fourth of July, the people of the United States proudly reaffirm the bold words of Thomas Jefferson that, «We hold these Truths to be self-evident, that all Men Are Created Equal, that they are endowed by their Creator with certain unalienable Rights, that among these are Life, Liberty, and the Pursuit of Happiness.» Jefferson's words are as true today as when first written.

To reiterate, I wish to say in the strongest terms I can muster, emboldened by the courage and fortitude of immigrants throughout the world and throughout history, that we should not be devising schemes and rationalisations for the restriction of liberty.

Rather, let US take part in the fight against fear, prejudice, custom and law to champion freedom. This is practical, humanitarian and, above all, ethical. Let US be a part of the drive for 
liberty today. Let US champion the millions of immigrants who are seeking liberty in the same manner that we would if we were in their shoes. ${ }^{32}$

\section{BIBLIOGRAPHICAL REFERENCES}

BLOCK, W. (1998): «A Libertarian Case for Free Immigration», The Journal of Libertarian Studies, 13:2 (Summer), pp. 167-186.

BoudREAUX, D. (2002): «Absorbing Immigrants», Ideas on Liberty, Foundation for Economic Education, June, p. 54.

Brumfiel, G. (2004): «Security restrictions lead foreign students to snub US universities», News@nature.com, September 15.

Cox, W.M. and Alm, R. (2002): "Off the Books», Reason, August, p. 48.

FERGUSON, E. (2004): «Skilled US workers lose jobs: Visa programs give positions to recruits from overseas,» Honolulu Advertiser, December 20.

FinleY, B. (2004): «US takes border war on the road: Boats being sunk near Ecuador», Denver Post, December 19.

Honolulu Advertiser (1993a): «\$24,000 cruise ship fine for rescuing 8 Cubans,» Oct. 22.

- (1993b): «Piracy done with fines,» Nov. 6.

- (2000): «Iran coup mastermind Kermit Roosevelt dies», $6 / 11$.

Hoppe, H.H. (1998): «The Case for Free Trade and Restricted Immigration», The Journal of Libertarian Studies, 13:2 (Summer), pp. 221-233.

HorberGER, J.G. (1995): «Locking Out the Immigrant,» The Case For Free Trade and Open Immigration, p. 93, The Future of Freedom Foundation, Fairfax, Virginia. http://www. denverpost.com/Stories/0,1413,36 11676 2606736,00.html

IJAZ, M. (2001): «Clinton let bin Laden get away», Honolulu Advertiser, December 10.

INVESTORS BusinesS DAiLy (2000): «An End to Poverty?», October 19. - (2002): «World Defense Spending», October 18, p. A16

32 Schoolland (2002). 
Mitra, B.S. (2000), Ed.: Population: The Ultimate Resource, Liberty Institute, New Delhi, India.

Moore, S. (1995): «Why Welfare Pays», Wall Street Journal, September 28.

OMICINSKI, J. (1994): «US dealers dominating world arms market», Honolulu Advertiser, April 17.

Piller, Ch. (2004): «"Brain drain" flowing from US to Asia,» Honolulu Advertiser, December 12.

Powell, C. (2004): «Secure Borders, Open Doors», Wall Street Journal, April 21.

Schoolland, K. (2002): «Immigration: An Abolitionist Cause», Ideas on Liberty, January.

SHAPIRO, T. (2002): «Conference to spotlight trafficking in humans,» Honolulu Star-Bulletin, June 13, p. A6.

SIMON, J. (1995): «Immigration: The Demographic and Economic Facts», The Cato Institute, Washington, D.C., pp. 3-5.

Solberg, C. (1976): Oil Power, New York: Mason/Charter.

Stagnaro, C. (2004): «When Your Mother Kills», Tech Central Station, December 28, http: / / www.techcentralstation.com/ 122804B.html

SteWART, R. (1998): A Free and Autonomous Region, Litografía e Imprenta LIL, S.A, San Jose, Costa Rica, 2000, drawing from the excellent research of José Cordiero of Venezuela, including The Great Taboo: A True Nationalization of the Venezuelan Petroleum.

The ECONOMist (1999): «Refugees: Exporting misery», Apr. 17.

- (2001): «Patches of Light: Special Report on Agricultural Trade», June 9.

- (2002a): «Nostra Culpa», March 30, pp. 27-28.

- (2002b): «Inept National Security», March 23.

- (2002c): «A cargo of exploitable souls», June 1, p. 30.

- (2002d): «Europe's Farms», 7/13, p 42.

- (2002e): «Subsidized cow chow», March 9, p. 39.

THE ECONOMIC TIMES (2004): «NRI's among US's superachievers,» December 30, http://economictimes.indiatimes.com/ articleshow/msid-975426, curpg-1.cms

TracinSKI, R.W. (2002): "Opposition to Immigration is UnAmerican: Restrictions on "H-1B" Visas Punish Ability 
and Trample the Rights of Employer and Employee», Ayn Rand Institute, http://www.aynrand.org/medialink/ immigration.txt

U.S. Census Bureau (2003): «Migration of Natives and the Foreign Born: 1995-2000», August. 


\section{APPENDIX}

\section{I \\ FRÉDÉRIC BASTIAT AND IMMIGRATION}

IN WRITING his famous "Candlemakers» Petition", the famous $19^{\text {th }}$ Century French economist, Frédéric Bastiat, did not address the issue of immigration, but he did write about the treatment of Polish refugees who had fled persecution and were being harassed and deported by French authorities. Wrote Bastiat:

...the most ardent wish of a refugee, after the one of ending his exile, is to practise some trade in order to create some resources for his survival. But for that, he must choose the location of his residence; those who can be useful in commercial enterprises should be able to go to towns where there are such enterprises, those who want to do some industrial activity should be able to go to industrial regions, those who have some talents should go to cities encouraging those talents. Furthermore, they should not be expelled at any moment, nor live with the sword of arbitrary measures hanging above their heads.

In fond remembrance of Frédéric Bastiat, on the celebration of 200 years since his birth, allow me to parody this topic in a manner that Bastiat might appreciate. One of Bastiat's most famous essays was about candle makers who wanted to ban light and heat from the sun in order to protect local industry. Why not protect labour in a similar manner?

\section{II}

\section{THE PETITION OF THE CANDLEMAKERS, PART DEUX}

From the Makers of Candles, Tapers, Lanterns, Candlesticks, Street Lamps, Snuffers, and Extinguishers, and from the Producers of Tallow, Oil, Resin, Alcohol, and Generally of Everything Connected with Working. 
To the Honorable Members of the Chamber of Deputies. Gentlemen:

We are suffering from the ruinous competition of rivals who apparently work in such a far superior manner that they are flooding the domestic market with great diligence and an incredibly low price. From the moment they begin to work, our work ceases, all the consumers turn to them, and a branch of French labour whose ramifications are innumerable is all at once reduced to complete stagnation. These rivals are appearing everywhere around US, they are none other than millions of birth newcomers-infants born into our midst, destined to take our jobs and our industry.

We ask you to be so good as to pass a law requiring the closing of all openings through which they might enter to destroy our livelihood-in short, seal all wombs and secure these passages by the engagement of all necessary guards and patrols.

Be good enough, honorable deputies, to take our request seriously, and do not reject it without at least hearing the reasons that we have to advance in its support.

First, if you shut off all access to natural births, and thereby create a greater need for existing workers, what labourers toiling in France today will not ultimately be encouraged? We should surely see a demand grow such that workers will command increased compensations well beyond their hundredth year!

Surely you must recognise the drain of these birth newcomers on the creative energies of society. They come to this land with no knowledge of our customs or our language. These infants are bereft of civility or even the rudiments of good manners.

These new newcomers have no skills whatsoever, they cannot support themselves in the slightest, and, worse yet, they are absolutely certain to be a drain on our national and cultural resources for a score of years before they will compensate society in any substantial form.

We anticipate your objections, gentlemen; but there is not a single one of them that you have not picked up from the musty old books of the advocates of human rights. Will you say that the labour of birth newcomers is a gratuitous gift of Nature, and that to reject such gifts would be to reject wealth itself under the pretext of encouraging the means of acquiring it? 
But if you take this position, you strike a mortal blow at your own policy; remember that up to now you have always excluded foreign labour on similar grounds.

\section{III}

\section{EMIGRATION HYPOCRISY}

THROUGHOUT MY research on the subject I was astounded to learn that there is one country above all others that tolerates an extraordinary level of out-migration. Unbelievably, that nationstate allows four to ten million of its citizens to move and reside abroad. That's right, four to ten million citizens living outside of its borders.

These people are fleeing their country for a variety of political and economic reasons. A few criminal and political elements are escaping a home government that would jail them for offences ranging from drug trafficking to tax evasion. But most of these are economic migrants who have moved abroad simply to improve their economic condition. Sometimes they hand over a lifetime of savings to clever agents who arrange for their travel in closed compartments across hot deserts and shark-infested seas.

This invasion of countries abroad has led to considerable displacement where they undoubtedly do work that might otherwise be done by local inhabitants. Most of these new arrivals are unfamiliar with the language, the manners, and the customs of their new home and they stubbornly cling to the language, customs, and eating habits of their Old World - typically congregating at McDonald's restaurants worldwide.

Their families frequently congregate in isolated ethnic enclaves; they are loath to mixing in with the native population. Indeed, they are usually preoccupied with sending money home and arranging for relatives to join them.

They keep strong ties with the homeland and their loyalty to the new, adopted home is always suspect. Worse yet, these newcomers are parasites on the services and amenities that have been established by countless generations of taxpayers who built the infrastructure before their arrival. 
And yet rarely does anyone ever protest this out-migration of four to ten million businessmen and their families from the United States of America. Why not?

The movement of Americans abroad is generally perceived as an economic benefit to the nation-states that receive them. They are openly courted. Indeed, people in the wealthier nation-states of America, Asia and Europe expect to be allowed to travel the world at will, yet they are far less accepting of people from poorer neighborhoods.

\section{IV}

\section{AS IF PEOPLE WERE AS VALUABLE AS OIL}

The President has just declared a national emergency. He is responding to the recent press release from the meeting of the Organisation for People Exporting Countries (OPEC). OPEC announced today that the number of people allowed to leave their countries for destinations abroad will be cut by ten percent in order to maintain labour prices at historically high levels abroad.

A joint meeting of Congress has been scheduled to hear the full presidential address. An advance copy of his speech has been delivered to the press. In his speech the President issues a strong warning to the OPEC nations that this development on the restriction of people coming to the US is to be viewed as the «moral equivalent of war» because of the adverse affects on the American economy and international economic competitiveness.

«This nation», warned the President in prepared comments, «has dedicated the lives and fortunes of our countrymen to guarantee the free flow of petroleum from around the world because we recognise the value of raw fuel to the development possibilities of our economy. If we will do all of this to import the most base of raw materials, do you think that we would do anything less for the most sophisticated production miracles of history - evermore-precious human beings?

«Every human being is a marvel of the self-propelled, self-sustained miracle of production, innovation, genius, and reproduction! 
We will not tolerate efforts of OPEC to control and cripple the potential of our nation!»

In a simultaneous development, the President has instructed his Special Immigration Negotiator (SIN), to file a complaint with the World Immigration Organisation (WIO) charging OPEC with violating the multilateral treaty for the free flow of people across borders. The SIN has blasted the OPEC on previous occasions for interfering with the international competition for labour. 